\title{
Los silencios de la tradición
}

\section{Esther Cohen}

Ana María Martínez de la Escalera, Algo propio, algo distinto de sí. Ensayos sobre Dante, Gracián y la astucia del lenguaje. Barcelona, Anthropos/Fundación Cultural Eduardo Cohen, 2001.

(Biblioteca A. Conciencia, 42)

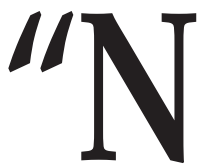

o existe documento de cultura que no sea a la vez documento de barbarie", escribe Walter Benjamin en su séptima tesis de filosofía de la historia. Y continúa: "Y puesto que el documento de cultura no es en sí inmune a la barbarie, no lo es tampoco el proceso de la tradición, a través del cual se pasa de lo uno a lo otro. Por lo tanto, el materialista histórico se distancia en la medida de lo posible. Considera que su misión es la de pasar por la historia el cepillo a contrapelo". Se podría decir, con Benjamin, que es justamente éste el punto de vista desde donde Ana María Martínez de la Escalera aborda la historia de la filosofía occidental, desde la perspectiva de ese materialista histórico que se atreve a recordar y a contar lo que la historia no se ha atrevido a poner de manifiesto y lo que la tradición filosófica ha callado. Porque se trata de poner en cuestión cierta autonomía de la filosofía frente a las artes retóricas, haciendo hablar a esa tradición excluida que quedó enterrada hacia finales del siglo XVII. La barbarie está ahí, presente en este oscurecimiento del pasado que ha arrojado a la retórica fuera del dominio de la filosofía. Y es a esa misma barbarie a la que este libro responde dándole un espacio, recuperando para el discurso filosófico una tradición retórica que desde siempre formó parte de su racionalidad. Hay un denominador común que atraviesa este libro de principio a fin, y es precisamente esta lectura a contrapelo que hace violencia a lo que conocemos como filosofía occidental contemporánea, es esta peculiar perspectiva, lugar desde donde se observa el pasado, lo que le imprime ese sello de responsabilidad y justicia frente a la historia de la filosofía. Ana María pretende recuperar esos silencios de la tradición, leyendo de nueva cuenta a Dante y a Gracián, momentos singulares a partir de los cuales, como ella misma escribe, "La filosofía moderna tuvo su origen en esa modificación que significó que lo filosófico se enajenara de lo retórico, como en otro momento de lo teológico y lo científico" (p. 11). 
Se trata, para ella, de recuperar las artes retóricas de la palabra para el bien de la filosofía contemporánea y ver en qué medida esta relación de "camaradería" entre filosofía y retórica que se mantuvo durante el Renacimiento y el barroco, fue interrumpida, podríamos decir, por la "barbarie" de una nueva racionalidad. Y para ello, es necesario detenerse en esos autores que de una u otra forma fueron el escenario de la fractura, no porque ellos lo hayan querido así, sino porque la crítica los colocó en ese otro lugar. La descalificación del Renacimiento como época significativa de la historia de la filosofia obliga a la autora a replantear algunos de los postulados del humanismo, que han sido pasados por alto por la crítica filosófica:

Hay que saber que [...] Sin el recurso a las operaciones retóricas tampoco sería posible sostener el principio de identidad y el principio del sujeto, que dan coherencia y unidad a lo dicho; ambos fundamentales para la edificación de la metafísica racionalista (que a decir de Heidegger es y ha sido, nuestra tradición filosófica). [...] sin el vocabulario con el que los autores posteriores a la Antigüedad armaron a sus seguidores, jamás esta tarea hubiera sido realizada. Me refiero al papel preponderante que adquieren las figuras retóricas en las obras de Nietzsche, en las que serían expuestas las contradicciones del principio de identidad, y donde se revelaría la condición alegórica del sujeto, es decir, como la representación sensible de una entidad ilusoria (p. 21).

Por todo ello, es necesario volver los ojos a Dante y ver hasta dónde su "filosofía de la palabra" presagiaba ya el pensamiento moderno, en qué medida sus virtudes retóricas parecían acercarse a las virtudes éticas y en qué sentido su recurso alegórico parece tener el propósito de tratar al lenguaje, o más bien al comportamiento del mismo, como si se tratase de comportamiento humano (p. 49). La lengua, en este sentido, no es un mero instrumento de comunicación sino un auténtico comportamiento comunitario y un valor adecuado a un sentido. Pasar el cepillo a contrapelo es volver a leer a Dante y al humanismo renacentista, sacando a la luz aquello que fue reducido a un simplón antropocentrismo para ponerlo al servicio de una filosofía que desconoce a sus antepasados o que, al límite, los ha abandonado en el olvido. Habrá que tender puentes con esta herencia, violentar a la crítica que ha pasado por alto el vínculo filosófico-retórico que se encuentra en el humanismo renacentista y, desde ahí, hacer hablar a una filosofía de la palabra a la que tanto debe la obra de nuestros pensadores contemporáneos, empezando por alguien como Nietzsche, quien marca el inicio de una nueva forma de concebir la filosofía.

Pero la herencia recuperada por este libro se extiende al siglo XVII, la deuda incluye a ese barroco que se presenta como un mundo de pluralidades 
diferentes, en tensión y conflicto, aunque no necesariamente antagónicas. Y aquí, Gracián es la figura a la que Ana María dedica un segundo ensayo para rescatarlo del silencio, para proyectarlo hacia el siglo xx y hacerle, en él, justicia. Porque las artes retóricas en Gracián no son meros ejercicios estilísticos, "naderías", como diría Borges, sino una verdadera puesta en cuestión de los usos mismos del lenguaje. De ahí la responsabilidad de la autora por asumir esta herencia vinculándola con la filosofía contemporánea, describiendo de manera minuciosa los aportes de un barroco, por lo menos desatendido. "La imagen de nosotros, entre el deber de sacar lecciones de la historia pasada y pensar al mismo tiempo, en un nuevo lenguaje, la singularidad de los acontecimientos nuevos, inéditos, es la imagen del compromiso barroco entre órdenes heterogéneos" (pp. 60-61). Y es este mismo principio el que parece regir la propia lectura de Ana María: encontrar en el vínculo con el pasado, el aliento de un lenguaje inédito para hablar el presente y significarlo. Gracián, íntegro representante del barroco, se preocupa por el problema de la verdad, pero para él, la verdad está siempre por llegar, y cuando llega, lo hace fuera de tiempo. En este mismo sentido, el escritor da la misma importancia a la verdad que a la expresión misma. ¡En cuántos aspectos, la lectura de este autor nos obliga a revisar la tradición filosófica, aprendiendo a escuchar esas voces del pasado sobre las que se construyen nuestras formas "inéditas" de leer el mundo! Porque la lectura es, para Gracián, el ejercicio del que emana el sentido, y así, puede haber engaño, quizá error, pero la interpretación pertenecerá a la naturaleza, a la vida, en tanto finalidad del lenguaje humano. Así, el engaño coexiste con el desengaño: ambos le pertenecen por igual a la vida y a la muerte de la lengua (p. 78). Qué tan cercano nos puede resultar Gracián, cuando leído a la luz de un filósofo como Nietzsche, y es efectivamente en la posibilidad de propiciar este encuentro en donde radica la justicia que ejerce la autora con plena responsabilidad filosófica. Lo heredado se pone al descubierto, Gracián y la filosofía contemporánea dialogan.

"La responsabilidad ante la comunidad, escribe la autora, exige que lo excluido regrese". Por ello es importante poner en cuestión el archivo del que depende la tradición, releer la historia, en este caso de la filosofía, a contrapelo, respondiendo con una violencia de otro cuño a la violencia de la exclusión. Ana María Martínez de la Escalera cumple con su tarea entregándonos la minuciosa lectura de una "falta", de dos ausencias en la historia de la filosofía contemporánea, sabiendo, sin embargo, que ninguna interpretación es total y para siempre, porque la interpretación es un fenómeno histórico y, como tal, sujeta al envejecimiento y a la muerte. Su lectura, sin embargo, logra transformar la "barbarie" del silencio en la civilización de la escritura. 